\title{
Correlative Studies on Physio-morphological Characteristics of Gir Bull Semen during Summer and Winter Seasons
}

\author{
Karuna P. Bambode ${ }^{1 *}$, J. P. Korde ${ }^{1}$, Mahesh Gupta ${ }^{1}$, K. B. Bahiram ${ }^{1}$, \\ Manoj Patil ${ }^{2}$, Rajendra Nikhate ${ }^{3}$, D. V. Patil ${ }^{4}$ and V. M. Sardar ${ }^{1}$ \\ ${ }^{1}$ Department of Veterinary Physiology, Nagpur Veterinary College, Nagpur- 440006, India \\ ${ }^{2}$ Department of Animal Reproduction Gynaecology \& Obstetrics, Nagpur Veterinary College, \\ Nagpur- 440006, India \\ ${ }^{3}$ Livestock development officer at Frozen semen laboratory, Amravati road, Nagpur, India \\ ${ }^{4}$ Department of Animal Genetic \& Breeding, Nagpur Veterinary College, Nagpur- 440006, \\ India \\ *Corresponding author
}

\section{A B S T R A C T}

\begin{tabular}{|l|}
\hline Key w or d s \\
Gir breeding bulls, \\
$\begin{array}{l}\text { Semen quality, } \\
\text { Winter, Summer }\end{array}$ \\
\hline Article Info \\
$\begin{array}{l}\text { Accepted: } \\
\text { 26 September } 2020 \\
\text { Available Online: } \\
\text { 10 October } 2020\end{array}$ \\
\hline
\end{tabular}

The objective of the present study was to investigate the seasonal effect on neat semen quality of Gir bulls. In the winter, a total of 27 ejaculates were collected and in the summer, 59 were collected from three healthy bulls. Ejaculates were collected on a weekly basis using the artificial vagina method $\left(42-45^{\circ} \mathrm{C}\right)$. Meteorological data were recorded daily during the experimental period. Semen samples were evaluated for ejaculated volume, initial motility, mass motility, sperm livability, hypo-osmotic swelling test (HOST), acrosomal integrity and sperm abnormalities. During winter season, initial motility, mass motility, sperm viability, HOST and sperm acrosomal integrity was significantly $(\mathrm{p}<0.05)$ lower compared to the summer season, while, ejaculate volume and sperm concentration was higher during summer. The season had no significant effect on sperm abnormalities. Mass motility was positively correlated with the initial motility $(\mathrm{r}=0.309)$, sperm viability $(\mathrm{r}=0.600)$, HOST $(\mathrm{r}=0.512)$, acrosomal integrity $(\mathrm{r}=0.558)$, sperm abnormalities $(\mathrm{r}=0.027)$. Whereas, initial motility was positively correlated with the mass motility $(r=0.309)$, sperm viability $(r=0.127)$, HOST $(r=0.149)$, acrosomal integrity $(\mathrm{r}=0.210)$ and negatively correlated with sperm concentration $(\mathrm{r}=-0.123)$ and sperm abnormalities $(r=-0.450)$.

\section{Introduction}

The Girbreed of cattle is a popular Indian milch breed. This breed is the native of Kathiawar consisting of Junagadh, Bhavnagar, Rajkot and Amreli districts of
Gujarat. Gir breed has been conserved and bred successfully in the countries like Argentina, Mexico, USA, and Venezuela. This breed is adapted in various geographical locations under varying climatic conditions in India. It is pertinent that the adaptation in different geographical locations certainly 
affect the productivity of the breeding bulls, especially during heat stress in tropical environment. The impact of high ambient temperatures affects libido, testicular size, semen production and semen quality (Soderquist et al., 1996). The information regarding the effect of seasons on semen characteristics in dairy bulls has been reported to be of a conflicting nature (Bhakat et al., 2009) and some researchers have reported significant season effects (Rekwot et al., 1987; Goswami et al., 1991 and Singh and Raina, 2000), while others have found no seasonal effects (Mathur et al., 2002; Helbig et al., 2007) on semen quality parameters. The testicular temperature in most mammals is maintained at about $2-6^{\circ} \mathrm{C}$ below their body temperature for the production of morphologically normal and fertile spermatozoa (Waites, 1970).

Little information is available on seasonal variation in Gir semen quality production. The present study was carried out to evaluate the effect of winter and summer seasons on the morphological features of semen in Gir bulls and their correlation.

\section{Materials and Methods}

\section{Selection of animals and management practices}

Study was conducted on three healthy Gir bulls having three years of age with an average body weight of $350-400 \mathrm{~kg}$ available at the Frozen Semen Laboratory (FSL), Nagpur, India. Weekly ejaculates were collected in winter (December to February) and in summer (March to June) seasons in the early morning with sterilized artificial vagina $\left(42-45^{\circ} \mathrm{C}\right)$. The dry bulb temperature and wet bulb temperature was recorded on daily basis for calculating Temperature Humidity Index as per the formula described by McDowell (1972). Standard operational and management practices were followed considering the Standard Operating Procedures (SOP) \& Minimum Standard Protocol (MSP) of Government of India. All bulls were maintained at identical and optimal conditions of feeding and management practices throughout the period of study. In winter a total of 27 ejaculates were collected and 59 ejaculates were collected during the summer. Each ejaculate was processed to evaluate the ejaculated volume, initial motility, sperm concentration, mass motility, sperm livability, hypo-osmotic swelling test (HOST), acrosomal integrity and sperm abnormalities.

\section{Semen analysis}

Immediately after semen collection, ejaculated volume was recorded in a graduated glass centrifuge tube as per standard laboratory method. The initial motility was observed under a low power (10x) microscope on thermostatically controlled stage maintained at $37^{\circ} \mathrm{C}$ (Olympus BX41TF attached Progress CT3 camera with Progress capture Pro 2.6 software program made at Tokyo, Japan). The concentration of sperm (million/ml) in neat semen was determined by the Accucell bovine Photometer No. RS232, IMV Technology, France. The mass motility was measured from 0 to 5 scale based on the presence of vigour waves motions and swirls (Salisbury et al., 1978).Eosin-nigrosin (EN) stain was evaluated as a percentage of live spermatozoa as indicated by Blom (1977). About $10 \mu \mathrm{l}$ of neat semen was thoroughly mixed with $10 \mu \mathrm{l}$ of stain eosin-nigrosin at $37^{\circ} \mathrm{C}$ and a thin smear was prepared. About 200 sperm cells were counted under oil immersion objective lens $(100 x)$ of phase contrast microscope in different fields and are classified as live sperm cells having colorless head portions and dead sperm cells with pinkish or red coloration. Live sperm percentage has been determined. The HOST was carried out as per 
the method described by Jeyendran et al., 1984. The HOST reactive spermatozoa (A) and non-reactive spermatozoa (B) are shown in Plate 1.

Giemsa staining technique was used for evaluation of the acrosomal integrity in accordance with the methodology defined by Hancock (1952). About 200 spermatozoa were counted under oil immersion light microscope for intact acrosome at the head of spermatozoa (Plate 2).

\section{Statistical analysis}

Data obtained from the study was analyzed using t-test, correlation coefficients and presented as means \pm SE with the aid of SPSS statistical software, version (SPSS 20.0).

\section{Results and Discussion}

The weekly dry bulb (Tdb) and wet bulb (Twb) temperature were recorded between December to February (winter) and between March to June (summer). Temperature Humidity Index (THI) was determined using the McDowell (1972) formula. Table 1 displays the typical Tdb, Twb and THI values.

The environmental stresses on the Gir bulls were classified as described by McDowell (1972), where the THI above 72 is considered as thermal stress. Therefore, the THI of 88.32 \pm 1.61 in summer exhibited thermal stress on bulls and the THI of $70.21 \pm 1.25$ in winter shows that thermal stress was not on bulls.

Table 2 presents the results concerning semen characteristics of Gir bull fresh semen. Table 3 indicates the correlation between the different characteristics of the semen.

\section{Ejaculate volume}

Ejaculate volume in the summer was significantly $(\mathrm{p}<0.05)$ higher at higher THI. Similar findings have been reported in the
Tharparkar bulls, Hariana bulls and Karan Fries bulls by Rajoriya et al., (2015), Singh et al., (2018) and Bhakat et al., (2014).In contrast to the present results in Gir bulls and Karan Fries bulls by Das et al., (2017) and Soren et al., (2016) reported a higher ejaculate volume in winter than summer. The ejaculate volume is positively correlated to the initial motility $(\mathrm{r}=0.160)$, sperm concentration $(r=0.158)$ and has a negative correlation with the mass motility $(\mathrm{r}=-0.230)$, sperm viability $(\mathrm{r}=-0.248)$, HOST $(\mathrm{r}=$ $0.178)$, acrosomal integrity $(\mathrm{r}=-0.096)$ and abnormalities of sperm $(\mathrm{r}=-0.218)$ as shown in table 3 .

\section{Initial motility}

The significantly $(\mathrm{p}<0.05)$ higher initial motility was recorded during winter than in summer. Similar to our results in Gir bulls, Hariana bulls and Karan Fries bulls were reported by Das et al., (2017), Singh et al., (2018) and Soren et al., (2016).Initial motility correlated positively with ejaculate volume $(\mathrm{r}=0.160)$, mass motility $(\mathrm{r}=0.309)$, sperm viability $\quad(\mathrm{r}=0.127), \quad$ HOST $\quad(\mathrm{r}=0.149)$, acrosomal integrity $(\mathrm{r}=0.210)$ and negative correlation with sperm concentration $(\mathrm{r}=$ $0.123)$ and sperm abnormalities $(r=-0.450)$ as shown in table 3 .

\section{Sperm concentration}

Significantly $\quad(\mathrm{p}<0.05) \quad$ higher $\quad$ sperm concentration was observed during summer season than the winter season. Similar findings in Hariana bulls and Nilli Ravi buffalo bulls with Singh et al., (2018) and Hameed et al., (2017). In contrast to present findings Das et al., (2017), Rajoriya et al., (2015) and Soren et al., (2016) reported the highest concentration of sperm during winter than summer season in Gir bulls, Tharparkar bulls and Karan Fries bulls respectively. Sperm concentration was positively correlated 
with the ejaculate volume $(r=0.158)$, mass motility $(\mathrm{r}=0.107)$, sperm viability $(\mathrm{r}=0.368)$, HOST ( $\mathrm{r}=0.009)$, acrosomal integrity $(\mathrm{r}=$ 0.374 ) and negative correlation with initial motility $(\mathrm{r}=-0.123)$, abnormalities of sperm $(r=-0.063)$ as shown in table 3. Similar correlation was reported by Rajoriya et al., (2015), significant positive correlation of sperm concentration with HOST $(p<0.01)$ positive sperm in the summer season.

\section{Mass motility}

Mass activity of Gir bull semen was significantly $(\mathrm{p}<0.05)$ higher in winter than summer season. Similar findings were reported in Hariana bulls and Murrah buffalo bulls by Singh et al., (2018) and Ram et al., (2017).Mass motility positively correlated with initial motility $(\mathrm{r}=0.309)$, sperm concentration $(\mathrm{r}=0.107)$, sperm viability $(\mathrm{r}=0.600), \quad$ HOST $\quad(\mathrm{r}=0.512), \quad$ acrosomal integrity $(\mathrm{r}=0.558), \quad$ sperm abnormalities $(\mathrm{r}=0.027)$ and negative correlated with ejaculate volume $(\mathrm{r}=-0.230)$ as shown in table 3. Similar correlation was reported by Rajoriya et al., (2015), Patel et al., (1989) and
Rafiq, (2009) mass activity has been significantly $(\mathrm{p}<0.01)$ positively correlated with sperm concentration, initial progressive motility, live percentage and acrosomal integrity in both summer and winter season.

\section{Sperm livability}

Significantly $(\mathrm{p}<0.05)$ higher sperm livability during winter as compared with summer season. Similar findings with Singh et al., (2018), Soren et al., (2016) and Bhakatet al., (2014) have been reported maximum sperm livability in Hariana bulls and Karan Fries bulls during the winter than summer season .In contrast to present finding by Rajoriya $e t$ al., (2015) reported maximum sperm livability during summer than winter season in Tharparkar bulls. The viability of sperm was positively correlated with initial motility $(\mathrm{r}=0.127)$, sperm concentration $(\mathrm{r}=0.368)$, mass motility $(\mathrm{r}=0.600)$, HOST $(\mathrm{r}=0.404)$, acrosomal integrity $(\mathrm{r}=0.441)$, sperm abnormalities $(\mathrm{r}=0.045)$ and negative correlation with ejaculate volume $(r=-0.248)$ as shown in table 3.

Table.1 Average environmental variables values during the experimental period

\begin{tabular}{|c|c|c|c|}
\hline Season & $\begin{array}{c}\text { Dry bulb temperature } \\
\mathbf{T}_{\mathbf{d b}}\left({ }^{\circ} \mathbf{C}\right)\end{array}$ & $\begin{array}{c}\text { Wet bulb temperature } \\
\mathbf{T}_{\mathbf{w b}}\left({ }^{\circ} \mathbf{C}\right)\end{array}$ & $\begin{array}{c}\text { Temperature Humidity Index } \\
(\mathbf{T H I})\end{array}$ \\
\hline Winter & $22.12 \pm 1.36$ & $20.62 \pm 0.96$ & $70.21 \pm 1.25$ \\
\hline Summer & $35.00 \pm 1.49^{*}$ & $31.28 \pm 0.77^{*}$ & $88.32 \pm 1.61^{*}$ \\
\hline
\end{tabular}

Table.2 Semen characteristics of fresh semen of Girbulls at different THI

\begin{tabular}{|c|c|c|c|}
\hline Sr. No. & Semen Parameters & $\begin{array}{c}\text { Winter season } \\
\text { (THI 72.91) } \mathbf{( N = 2 7 )}\end{array}$ & $\begin{array}{c}\text { Summer season } \\
\text { (THI 88.32) }(\mathbf{N}=59)\end{array}$ \\
\hline $\mathbf{1 .}$ & Ejaculate volume (ml) & $4.45 \pm 0.28$ & $5.69 \pm 0.21^{*}$ \\
\hline $\mathbf{2 .}$ & Initial motility (\%) & $72.70 \pm 1.19^{*}$ & $65.37 \pm 1.38$ \\
\hline $\mathbf{3 .}$ & Sperm concentration (million/ml) & $879.25 \pm 64.01$ & $1192.38 \pm 66.18^{*}$ \\
\hline $\mathbf{4 .}$ & Mass motility (0-5 scale) & $3.40 \pm 0.09^{*}$ & $2.25 \pm 0.08$ \\
\hline $\mathbf{5 .}$ & Sperm viability (\%) & $77.59 \pm 1.26^{*}$ & $70.11 \pm 1.31$ \\
\hline $\mathbf{6 .}$ & HOST (\%) & $67.59 \pm 0.75^{*}$ & $58.03 \pm 1.28$ \\
\hline $\mathbf{7 .}$ & Acrosomal integrity (\%) & $75.14 \pm 1.11^{*}$ & $69.28 \pm 1.06$ \\
\hline $\mathbf{8 .}$ & Sperm abnormalities (\%) & $4.70 \pm 0.75$ & $5.00 \pm 1.50$ \\
\hline
\end{tabular}

* Represents significantly higher at $5 \%$ level 
Table.3 Correlation among the various seminal characteristics of fresh semen of Gir bulls

\begin{tabular}{|l|c|c|c|c|c|c|c|}
\hline & $\begin{array}{c}\text { Ejaculate } \\
\text { Volume }\end{array}$ & $\begin{array}{c}\text { Initial } \\
\text { Motility }\end{array}$ & $\begin{array}{c}\text { Sperm } \\
\text { Conc. }\end{array}$ & $\begin{array}{c}\text { Mass } \\
\text { motility }\end{array}$ & $\begin{array}{c}\text { Sperm } \\
\text { viability }\end{array}$ & HOST & $\begin{array}{c}\text { Acrosomal } \\
\text { integrity }\end{array}$ \\
\hline Ejaculate Volume & & & & & & & \\
\hline Initial Motility & 0.160 & & & & & & \\
\hline Sperm Concentration & 0.158 & -0.123 & & & & & \\
\hline Mass motility & -0.230 & 0.309 & 0.107 & & & & \\
\hline Sperm viability & -0.248 & 0.127 & 0.368 & 0.600 & & \\
\hline HOST & -0.178 & 0.149 & 0.009 & 0.512 & 0.404 & & \\
\hline Acrosomal integrity & -0.096 & 0.210 & 0.374 & 0.558 & 0.441 & 0.347 & -0.138 \\
\hline Sperm abnormalities & -0.218 & -0.450 & -0.063 & 0.027 & 0.045 & 0.115 & \\
\hline
\end{tabular}

Plate.1(A) HOST reactive spermatozoa (B) HOST non-reactive spermatozoa

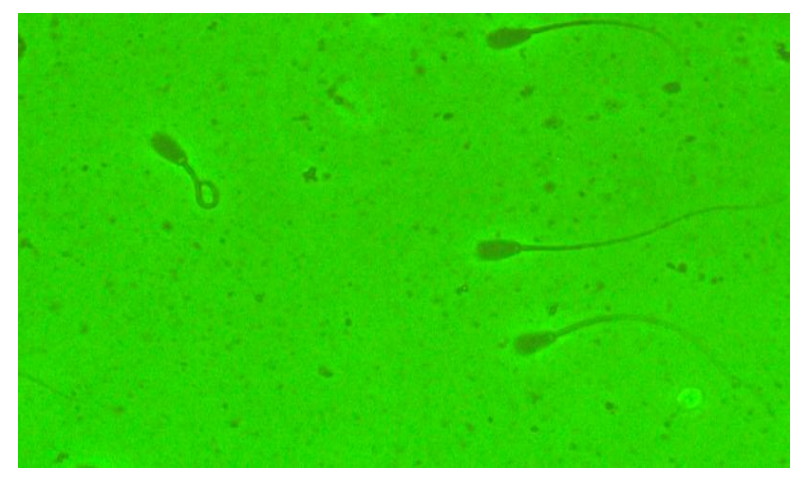

Plate.1 (A) HOST reactive spermatozoa

(B) HOST non-reactive spermatozoa

Plate 2.Live spermatozoa with healthy acrosome were identified as light rose colored post acrozomal area and pink acrozomalarea in the sperm head

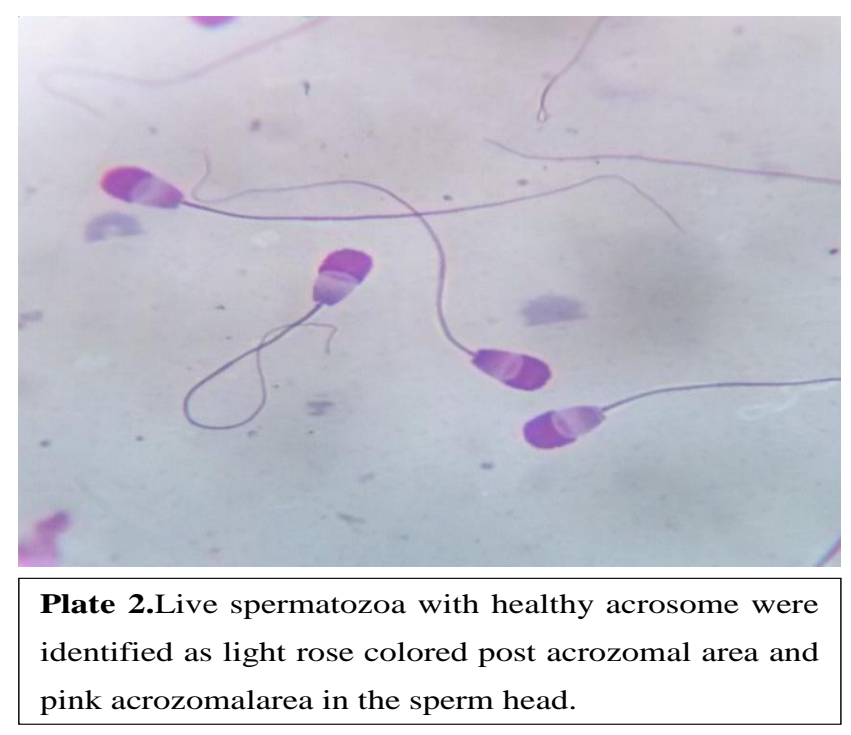




\section{Hypo-osmotic swelling test (HOST)}

Total HOST reactive spermatozoa significantly $(\mathrm{p}<0.05) \quad$ maximum during winter season than summer.

Similar findings were recorded in the Hariana bulls, Tharparkar bulls and Karan Fries bulls by Singh et al., (2018), Rajoriya et al., (2015) and Soren et al., (2016). HOST positively correlated with initial motility $(\mathrm{r}=0.149)$, sperm concentration $(\mathrm{r}=0.009)$, mass motility $(r=0.512)$, viability of sperm $(r=0.404)$, acrosomal integrity $(\mathrm{r}=0.347)$, sperm abnormalities $(\mathrm{r}=0.115)$ and negatively correlated with ejaculate volume $(\mathrm{r}=-0.178)$ as shown in Table 3.

Similar correlation was reported by Rajoriya et al., (2015) where, HOST positive spermatozoa were positively correlated with progressive motile $(\mathrm{p}<0.05)$, live percentage $(\mathrm{p}<0.01)$ and acrosomal integrity $(\mathrm{p}<0.01)$ in both the seasons in Tharparkarbull semen.

\section{Acrosomal integrity}

During winter, the acrosomal integrity was significantly $(\mathrm{p}<0.05)$ higher during winter as compared to summer season. Similar to our results finding on Hariana bulls and Karan Fries bulls reported by Singh et al., (2018), Bhakat et al., (2014) and Soren et al., (2016).

Positively correlation with initial motility $(\mathrm{r}=0.210)$, sperm concentration $(\mathrm{r}=0.374)$, mass motility ( $\mathrm{r}=0.558)$, viability of sperm $(\mathrm{r}=0.441)$, HOST $(r=0.347)$ and negative correlation with ejaculate volume $(\mathrm{r}=\quad-0.096)$, sperm abnormalities $(\mathrm{r}=-0.138)$ as shown in Table 3.

\section{Sperm abnormalities}

In both winter and summer season there was no significant difference observed. Higher sperm abnormalities in summer than winter season are observed with Singh et al., (2018), Bhakat et al., (2014) and Ram et al., (2017) in Hariana bulls, Karan Fries bulls and Murrah buffalo bulls.

In contrast to present findings of Rajoriya $e t$ al., (2015) higher sperm abnormalities in Tharparkar bulls in the winter than summer season. Sperm abnormalities positively correlated to the mass motility $(r=0.027)$, sperm viability $(\mathrm{r}=0.045)$, HOST $(\mathrm{r}=0.115)$ and negative correlation with ejaculate volume $(\mathrm{r}=-0.218)$, initial motility $(\mathrm{r}=$ $0.450)$, sperm concentration $(r=-0.063)$, acrosomal integrity $(r=-0.138)$ as shown in Table 3 .

It is concluded that the semen quality adversely affect during high THI in Gir bull semen, however, the ejaculate volume and sperm concentration improves. The sperm abnormality parameter remains unaffected by high THI.

Correlation study concluded that, most of the semen quality parameters of Gir bulls positively correlated with each other and negatively correlate with ejaculate volume except initial motility and sperm concentration. The physio-morphological characteristics dynamically interact with each other.

\section{References}

Bhakat, M., Mohanty, T. K., Gupta, A. K. and Abdullah, M. (2014). Effect of season on Semen Quality of Crossbred (Karan Fries) Bulls. Adv. Anim. Vet. Sci. 2(11): 632-637.

Bhakat, M., Mohanty, T.K., Gupta, A.K. and Raina, V.S. (2009). Effect of season and management on semen quality of breeding bulls- a review. Agri. Rev. 30(2): 79-93.

Blom, E. (1977). The evaluation of bull semen with special reference to its use in artificial insemination. Ani Breed Abstr.19:648.

Das, S., Sana, D., Gupta, T., Chowdhury, S., Chakraborti, A., Biswas, J. and Sarkar, S. 
(2017). Seasonal variation in semen production parameters of Gir bulls reared under tropical climate. Indian Journal of Animal Reproduction. 38(2): 40-50.

Goswami, S.C., Mehta, S.N., Georgie, G.C., Dixit, V.P., Lohan, I.S. and Kaker, M.L. (1991). Effect of meteorological factors and seasons on luteinizing hormone, testosterone and semen of zebu-taurus bulls. Indian $\mathrm{J}$ Anim. Sci. 61(6): 579-583.

Hancock, J.L. (1952). The Morphology of bull spermatozoa. J. Exp. Biol. 29:445-453.

Helbig, L., Woodbury, M.R., Haigh, J.C., Collins, J. and Barth, A.D. (2007). The seasonal fertility of North American bison (Bison bison) bulls. Anim. Reprod. Sci. 97(3-4): 265-277.

Jeyendran, R.S., Van der Ven, H.H., Perez-Pelaez, M., Carbo, B.G. andZaneveld, L.J.D. (1984). Development of an assay to assess the functional integrity of the human sperm membrane and its relationship to other semen characteristics. J. Reprod. Fertil. 70:219-228.

Mathur AK, Tyagi S, Singh SP. Frieswal bull an experience of HF with Sahiwal. J Livest Poultry Prod 2002; 18(1-2):21-23.

McDowell RE. Improvement of Livestock Production in Warm Climates. San Francisco, CA, USA: W.H. Freeman and Company Publishers. 1972; 51-53.

McDowell, R. E. 1972. Improvement of Livestock Production in Warm Climates. San Francisco, CA, USA: W.H. Freeman and Company Publishers. 51-53.

Rajoriya, J.S., Prasad, J.K., Ghosh, S.K., Kumar, A., Ramteke, S. S., Singh, M. and Kumar, S. (2015). Effect of peak winter and summer season on quality and freezability of Tharparkar bull semen. Indian J. Anim. Res., 49(2): 265-268.

Ram, K. L., Tiwari, R. P., Mishra, G.K.,
Sahasrabudhe, S.A. and Nair, A. K. (2017). Effect of heat stress on seminal characteristics of Murrah buffalo bull semen. Buffalo Bulletin. 36(2): 369-378.

Rekwot, P I., Voh, A.A., Oyedipe, E.O. Jr., Opaluwa, G.I., Sekoni, V.O. andDawuda, P.M. (1987). Influence of season on characteristics of the ejaculates from the bulls in an artificial insemination centre in Nigeria. Anim Reprod. Sci. 14(3): 187-194.

Salisbury GW, VanDemark NL, Lodge JR. Physiology of Reproduction and Artificial Insemination of Cattle, 2nd ed. W.H. Freeman and Co, San Francisco. 1978; 788.

Singh P. and Raina V.S. (2000). Effect of caffeine, cAMP and cattle seminal plasma on freezability of buffalo bull semen. Asian Austral. J. Anim. 13(7): 901-90.

Singh, V., Kumar, A., Yadav, C. L., Patel, A., Yadav, B. and Saxena, A. (2018). Effect of Season on Physico-Morphological Attributes of Cryopreserved Hariana Bull Spermatozoa. The Indian Journal of Veterinary Sciences \& Biotechnology. 14(1): 47-51.

Soderquist, L., Janson, L., Haard, M. and Einarsson, S. (1996). Influence of season, age and breed and some other factors on the variation in sperm morphological abnormalities in Swedish dairy A I bulls. Anim. Reprod. Sci., 44: 91-98.

Soren, S., Singh, S. V. and Kumar, A. (2016). Influence of Season on Semen Quality in Karan Fries (Tharparkarx Holstein Friesian) Bulls. Journal of Animal Research. 6(2): 121-125.

Waites G M.H. (1970). Temperature regulation and the testis. In: Johnson AD, Gomes WR, Yandemark NL (eds), The Testis. Academic Press, New York, NY, pp. 241-279.

\section{How to cite this article:}

Karuna P. Bambode, J. P. Korde, Mahesh Gupta, K. B. Bahiram, Manoj Patil, Rajendra Nikhate, D. V. Patil and Sardar, V. M. 2020. Correlative Studies on Physio-morphological Characteristics of Gir Bull Semen during Summer and Winter Seasons. Int.J.Curr.Microbiol.App.Sci. 9(10): 3185-3191. doi: https://doi.org/10.20546/ijcmas.2020.910.381 